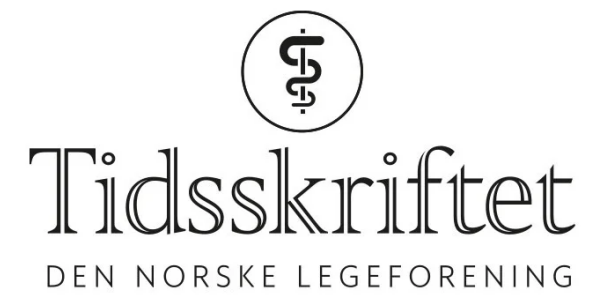

\title{
Leger med kortere vakter gjorde flest feil
}

FRA ANDRE TIDSSKRIFTER

SOFIE PAUS

Tidsskriftet

De av legene på intensivavdelinger som hadde kortere vakter, gjorde flere alvorlige feil enn dem som gikk i lange vakter. 


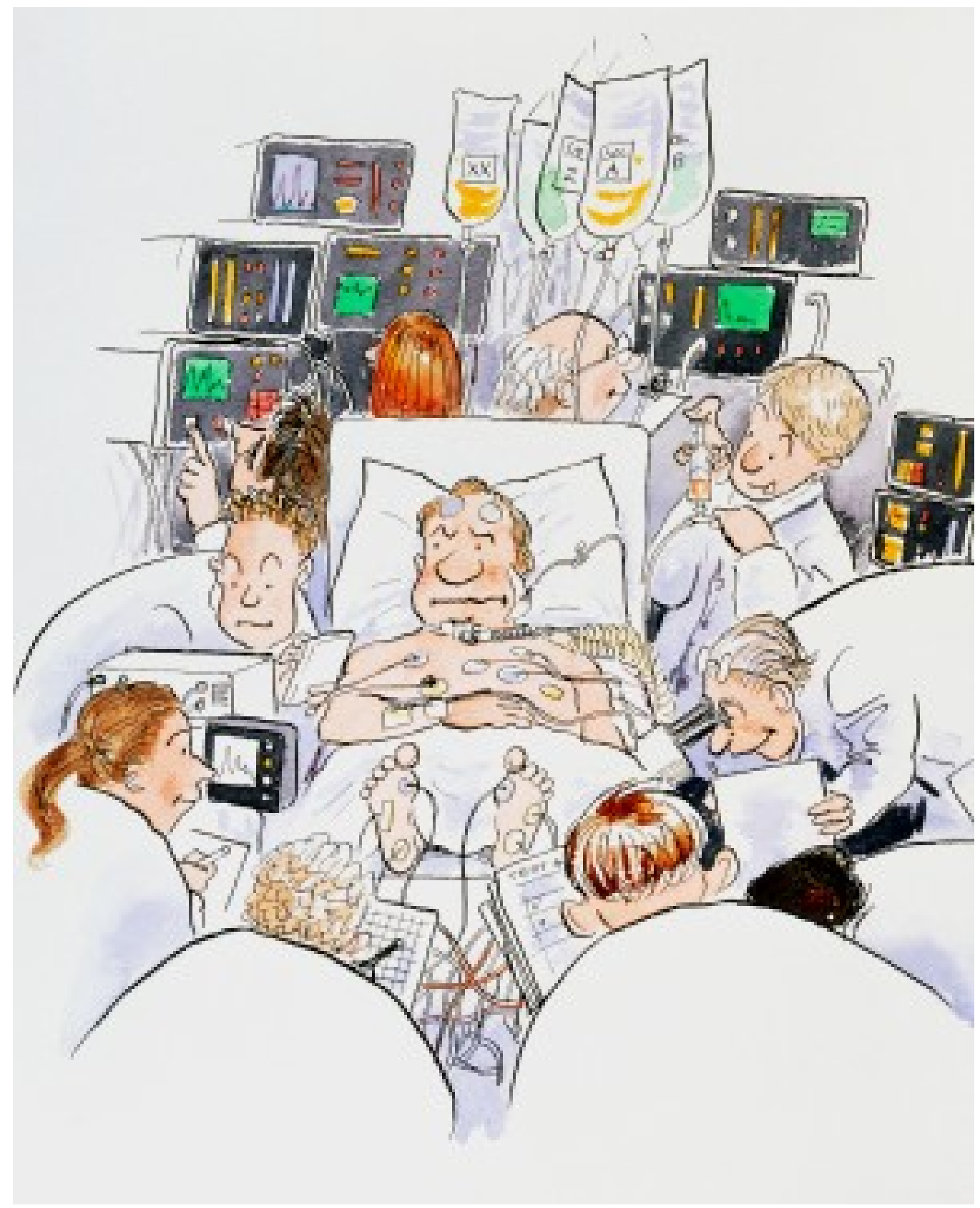

Illustrasjon: Science photo library / NTB Scanpix

Mange mener at lange vakter for sykehusleger innebærer høy risiko for å gjøre alvorlige feil. Denne hypotesen ble testet ut i en klyngerandomisert studie der deltakerne var leger $\mathrm{i}$ spesialisering i barnesykdommer ved seks sykehus (1). De hadde enten kortere vakter, definert som inntil 16 timer, eller lange vakter, definert som 24 timer eller mer.

Legene med kortere vakter gjorde flere feil enn dem med lange vakter, henholdsvis 97,1 mot 79,o feil per 1 ooo pasientdager, noe som gir en relativ risiko for feil på 1,52 ( $95 \%$ KI 1,37-1,72). Antall pasienter per lege var i snitt høyest for dem med kortere vakter. Ved justering for antall pasienter per lege var kortere vakter ikke assosiert med flere feil. Resultatene varierte dessuten mye mellom sykehusene.

- Dette er en metodisk sett godt gjennomført studie, men med noe sprikende resultater, sier Karin Isaksson Rø, som er spesialist i arbeidsmedisin og leder av LEFO Legeforskningsinstituttet.

- Samlet sett tyder resultatene på at det er arbeidsmengde, dvs. antall pasienter per lege og tidsenhet, som har betydning for antall feil som gjøres, sier hun. 
- Dette funnet er i tråd med studier som viser at opplevd arbeidspress kan være en vel så viktig risikofaktor for slitenhet og stressrelaterte tilstander blant leger som lang arbeidstid. I tillegg var legenes ukearbeidstid i denne studien over 62 timer per uke, uansett type vakter, og så lange arbeidsuker kan gjøre det vanskelig å få til en god jobb-hjem-balanse og å sikre egne behov og egen helse. Dette kan ha betydning for antall feil totalt sett.

- Mulige sammenhenger mellom legers arbeidskår og kvalitet i pasientbehandlingen er de siste årene satt på dagsordenen internasjonalt. Arbeidstid, både vaktlengde av enkeltvakter og total arbeidstid, er et av flere arbeidsforhold som er studert. Vi trenger mer kunnskap om de komplekse forhold som påvirker god pasientbehandling, legers arbeidsforhold og sammenhengene mellom disse, sier Rø.

\section{LITTERATUR}

1. Landrigan CP, Rahman SA, Sullivan JP et al. Effect on patient safety of a resident physician schedule without 24-hour shifts. N Engl J Med 2020;382: 2514-23. [PubMed][CrossRef]

Publisert: 7. september 2020. Tidsskr Nor Legeforen. DOI: 10.4045/tidsskr.20.0629

(C) Tidsskrift for Den norske legeforening 2023. Lastet ned fra tidsskriftet.no 26. april 2023. 